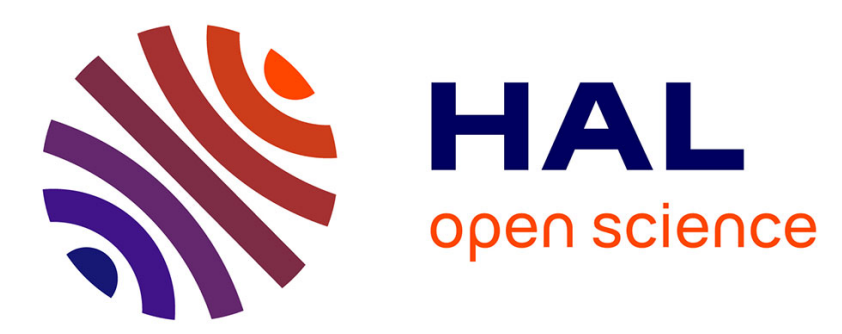

\title{
Domoic acid excretion in dungeness crabs, razor clams and mussels
}

\author{
Irvin R. Schultz, Ann Skillman, Dana Woodruff
}

\section{To cite this version:}

Irvin R. Schultz, Ann Skillman, Dana Woodruff. Domoic acid excretion in dungeness crabs, razor clams and mussels. Marine Environmental Research, 2008, 66 (1), pp.21. 10.1016/j.marenvres.2008.02.012 . hal-00563008

\section{HAL Id: hal-00563008 \\ https://hal.science/hal-00563008}

Submitted on 4 Feb 2011

HAL is a multi-disciplinary open access archive for the deposit and dissemination of scientific research documents, whether they are published or not. The documents may come from teaching and research institutions in France or abroad, or from public or private research centers.
L'archive ouverte pluridisciplinaire HAL, est destinée au dépôt et à la diffusion de documents scientifiques de niveau recherche, publiés ou non, émanant des établissements d'enseignement et de recherche français ou étrangers, des laboratoires publics ou privés. 


\section{Accepted Manuscript}

Domoic acid excretion in dungeness crabs, razor clams and mussels

Irvin R. Schultz, Ann Skillman, Dana Woodruff

PII:

S0141-1136(08)00028-7

DOI:

10.1016/j.marenvres.2008.02.012

Reference:

MERE 3180

To appear in:

Marine Environmental Research

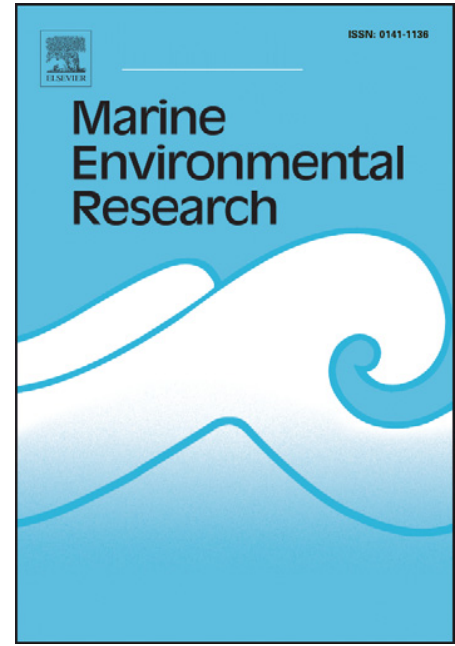

Please cite this article as: Schultz, I.R., Skillman, A., Woodruff, D., Domoic acid excretion in dungeness crabs, razor clams and mussels, Marine Environmental Research (2008), doi: 10.1016/j.marenvres.2008.02.012

This is a PDF file of an unedited manuscript that has been accepted for publication. As a service to our customers we are providing this early version of the manuscript. The manuscript will undergo copyediting, typesetting, and review of the resulting proof before it is published in its final form. Please note that during the production process errors may be discovered which could affect the content, and all legal disclaimers that apply to the journal pertain. 


\title{
Domoic acid excretion in dungeness crabs, razor clams and mussels
}

\author{
Irvin R. Schultz *, Ann Skillman, Dana Woodruff
}

Battelle, Pacific Northwest Division - Marine Sciences Laboratory, 1529 W Sequim Bay Rd., Sequim, WA 98382

\begin{abstract}
Domoic acid (DA) is a neurotoxic amino acid produced by several marine algal species of the Pseudo-nitzschia (PN) genus. We studied the elimination of DA from hemolymph after intravascular (IV) injection in razor clams (Siliqua patula), mussels (Mytilus edulis) and Dungeness crabs (Cancer magister). Crabs were also injected with two other organic acids, dichloroacetic acid (DCAA) and kainic acid (KA). For IV dosing, hemolymph was repetitively sampled and DA concentrations measured by HPLC-UV. Toxicokinetic analysis of DA in crabs suggested most of the injected dose remained within hemolymph compartment with little extravascular distribution. This observation is in sharp contrast to results obtained from clams and mussels which exhibited similarly large apparent volumes of distribution despite large differences in overall clearance. These findings suggest fundamentally different storage and elimination processes are occurring for DA between bivalves and crabs.
\end{abstract}

Keywords: Domoic acid; Bivalves; Crabs; Toxicokinetics

*Corresponding author: Tel +360 681 4566; Fax +360 6814599 
E-mail address: ir_Schultz@pnl.gov (I. Schultz)

The marine algal toxin domoic acid (DA), produced primarily by several species of pennate marine diatoms of the Pseudo-nitzschia (PN) genus is the causative agent of amnesic shellfish poisoning. High levels of DA have been periodically found in razor clams Siliqua patula and Dungeness crabs Cancer magister along the Pacific Coast of Washington (Wekell et al., 1994). A few studies have examined the disposition of DA in crabs. An early biomonitoring effort, measured DA in viscera (unspecified tissues) ranging from 0.8 to $30 \mathrm{mg} / \mathrm{kg}$ (Wekell et al., 1994). Similar levels of DA were still observed 3-4 months later in crabs captured from the same estuaries. The assimilation efficiency of DA in crabs after four consecutive daily feedings of razor clam meat was observed to be $68 \%$ based on hepatopancreas levels (Lund et al., 1997). In this study, $16 \%$ of the first dose was detectable in the hepatopancreas after four hours, which still had increasing concentrations of DA 24 hours after the last feeding (Lund et al., 1997). These results suggest that DA is rapidly and extensively absorbed from the digestive system in crabs.

Profound differences in the toxicokinetics of DA have been identified in a wide variety of shellfish including several species of mussels (Mytilus sp.; Wohlgeschaffen et al., 1992, Blanco et al., 2002) and razor clams (Drum et al., 1993). Depuration of DA in field-exposed mussels has been reported to be both mono-exponential (Novaczek et al., 1992) and bi-exponential (Blanco et al., 2002), although in both studies $>90 \%$ of the toxin was eliminated within 96 hours. Mussels retain most of the toxin in the digestive gland and the kidney with low levels found in the hemolymph (Novaczek et al., 1991). 
In this study, we applied an experimental approach involving direct intravascular injection of DA in mussels, clams and crabs and subsequent characterization of the toxicokinetics using a similar compartmental model. Additional experiments with crabs studied the elimination of two other organic acids, dichloroacetic (DCAA) and kainic (KA) acids to provide a comparison to the DA results.

All crabs and mussels were collected from Sequim Bay WA, USA. Razor clams were collected from various sites along the WA coastline. Water quality values measured during the study were: temperature: $9.0-10.2^{\circ} \mathrm{C}, \mathrm{pH}$ : 7.9-8.1; salinity: $31.0 \%$; dissolved oxygen $8.2-8.9 \mathrm{mg} / \mathrm{L}$. After acclimation for at least two weeks, individuals were transferred into indoor holding tanks under otherwise similar conditions.

All shellfish were injected intravascularly with DA $(1.0 \mathrm{mg} / \mathrm{Kg}$; dissolved in Cortlands saline, $\mathrm{pH}$ 7.4). Separate crabs were also dosed dichloroacetic acid (DCAA; $9 \mathrm{mg} / \mathrm{Kg}$ ) and kainic acid (KA; $2 \mathrm{mg} / \mathrm{kg}$ ). Subsequent hemolymph samples were removed from different legs by inserting the sampling syringe into the pereiopod arteries and removing approximately $0.1-0.2 \mathrm{ml}$ of hemolymph. Bivalves were similarly injected at a point posterior from the gills.

Domoic acid was measured by HPLC using UV detection at $242 \mathrm{~nm}$ (Quilliam et al., 1995). KA was measured by fluorescent detection using methods described by James et al. (2000). DCAA was measured by GC-ECD as described by Schultz et al. (1999). After administration of the DA to all shellfish and DCAA or KA to crabs, the decline in hemolymph concentration-time profiles appeared bi-exponential and we chose to fit these data to a 2compartment clearance volume compartmental model using WinNONLIN. The toxicokinetic parameters are the apparent volumes of distribution (V1, V2), total body clearance $(\mathrm{Clb})$ and the elimination half-life $\left(\mathrm{t}^{1 / 2}\right)$. 
A summary of the hemolymph concentration-time profiles for clams and mussels is presented in Figure 1a and $1 \mathrm{~b}$ and for crabs in Figure 2A-C. In mussels, DA declines in a log-linear manner with a elimination half-life of $55 \mathrm{hrs}$ and a steady-state volume of distribution of $4746 \mathrm{ml} / \mathrm{kg}$ (Table 1). In clams, DA levels initially declined and then appeared to stop or even increase slightly. Kinetic analysis is thus limited to estimation of distributive volume which appears to be similar to that observed for mussels (Table 1). In contrast to the results from bivalves, the volume of distribution of DA in crabs was quite small (approximately $280 \mathrm{ml} / \mathrm{kg}$ ). This value is very similar to the hemolymph volume in crabs, suggesting very little of the injected DA dose distributed outside the vascular fluid compartment. Comparison with the results from the DCAA and KA experiments indicated these organic acids have larger distributive volumes than DA and greater clearance, although both DCAA and KA also primarily distributed into a large central pool or compartment (see V1 estimates, Table 1). The DA results in crabs are surprising given the established ability of the hepatopancreas to retain DA after oral dosing. Instead, most of the injected DA is retained in the hemolymph compartment suggesting a diffusional barrier exists, which prevents DA in the hemolymph from distributing into the hepatopancreas.

\section{Acknowledgement}

Financial support was provided by the US EPA-STAR grants program.

\section{References}

Blanco, J., de la Puente, M.B., Arevalo, F., Salgado, C., and Morono, A. (2002). Aquatic Living Resources, 15, 53-60. 
Drum, A.S., Siebens, T.L., Crecelius, E.A., and Elston, R.A. (1993). Journal of Shellfish Research, 12, 443-450.

James, K.J., Gillman, M., Lehane, M., and Gago-Martinez, A. (2000). Journal of Chromatography A, 871, 1-6.

Lund, J.A.K., Barnett, H.J., Hatfield, C.L., Gauglitz, E.J., Wekell, J.C., and Rasco, B. (1997). Journal of Shellfish Research, 16, 225-231.

Quilliam, M.A., Xie, M., Hardstaff, W.R. (1995). Journal of AOAC International, 78, 543-554.

Schultz, I.R., Merdink, J.L., Gonzalez-Leon, A.G., and Bull, R.J. (1999). Toxicology and Applied Pharmacology, 158, 103-114.

Wekell, J.C., Gauglitz, E.J., Barnett, H.J., Hatfield, C.L., and Eklund, M. (1994). Journal of Shellfish Research, 13, 587-593.

Wohlgeschaffen, G.D., Mann, K.H., Rao, D.V.S., and Pocklington, R. (1992). Journal of Applied Phycology, 4, 297-310. 
Table 1.

Summary of toxicokinetics parameters (TK) determined after intravascular dosing in razor clam, mussel and Dungeness crab.

Parameters were estimated from a nonlinear least squares fit of the mean values for observed data to a 2-compartment clearancevolume model. Parameter estimates and associated standard errors shown in the table were provided by the WinNONLIN program. n.d. = not determinable

\begin{tabular}{|c|c|c|c|c|c|}
\hline TK & Razor & Mussel & & geness crab & \\
\hline \multirow[t]{2}{*}{ Parameter } & Clam & & DA & DCAA & $\mathrm{KA}$ \\
\hline & $1 \mathrm{mg} / \mathrm{Kg} \mathrm{DA}$ & $1 \mathrm{mg} / \mathrm{Kg} \mathrm{DA}$ & $1 \mathrm{mg} / \mathrm{Kg} \mathrm{DA}$ & $9 \mathrm{mg} / \mathrm{kg}$ & $2 \mathrm{mg} / \mathrm{kg}$ \\
\hline $\mathrm{V} 1 \mathrm{ml} \mathrm{kg}_{-}{ }^{1}$ & $349 \pm 110$ & $646+$ & $131 \pm 5$ & $307 \pm 38$ & $423 \pm 10$ \\
\hline $\mathrm{V} 2 \mathrm{ml} \mathrm{kg-}^{1}$ & $5436 \pm 2200$ & $4100 \pm 135$ & $151 \pm 75$ & $158 \pm 16$ & $358 \pm 35$ \\
\hline 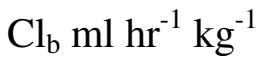 & n.d & & $1.5 \pm 0.2$ & $50 \pm 4.4$ & $6.1 \pm 1.0$ \\
\hline $\mathrm{t} 1 / 2(\mathrm{hr})$ & n.d & $55 \pm 27$ & $221 \pm 170$ & $221 \pm 170$ & $96 \pm 30$ \\
\hline
\end{tabular}




\section{Figure captions:}

Fig.1. Concentration-time profiles of DA in razor clams (A) and mussels (B) after direct intravascular injection of a $1 \mathrm{mg} / \mathrm{kg}$ dose. Data are mean $\pm \mathrm{SD}(\mathrm{n}=5-6)$. The solid line is the model predicted value based on the nonlinear least squares fitting of the observed data to a 2-compartment model.

Fig. 2. Concentration-time profiles of DA (A), DCAA (B) and KA (C) in Dungeness crabs after direct intravascular injection of a 1,9 or $2 \mathrm{mg} / \mathrm{kg}$ dose respectively. Data are mean $\pm \mathrm{SD}(\mathrm{n}=3-6)$. The solid line is the model predicted value based on the nonlinear least squares fitting of the observed data to a 2-compartment model. 
A)

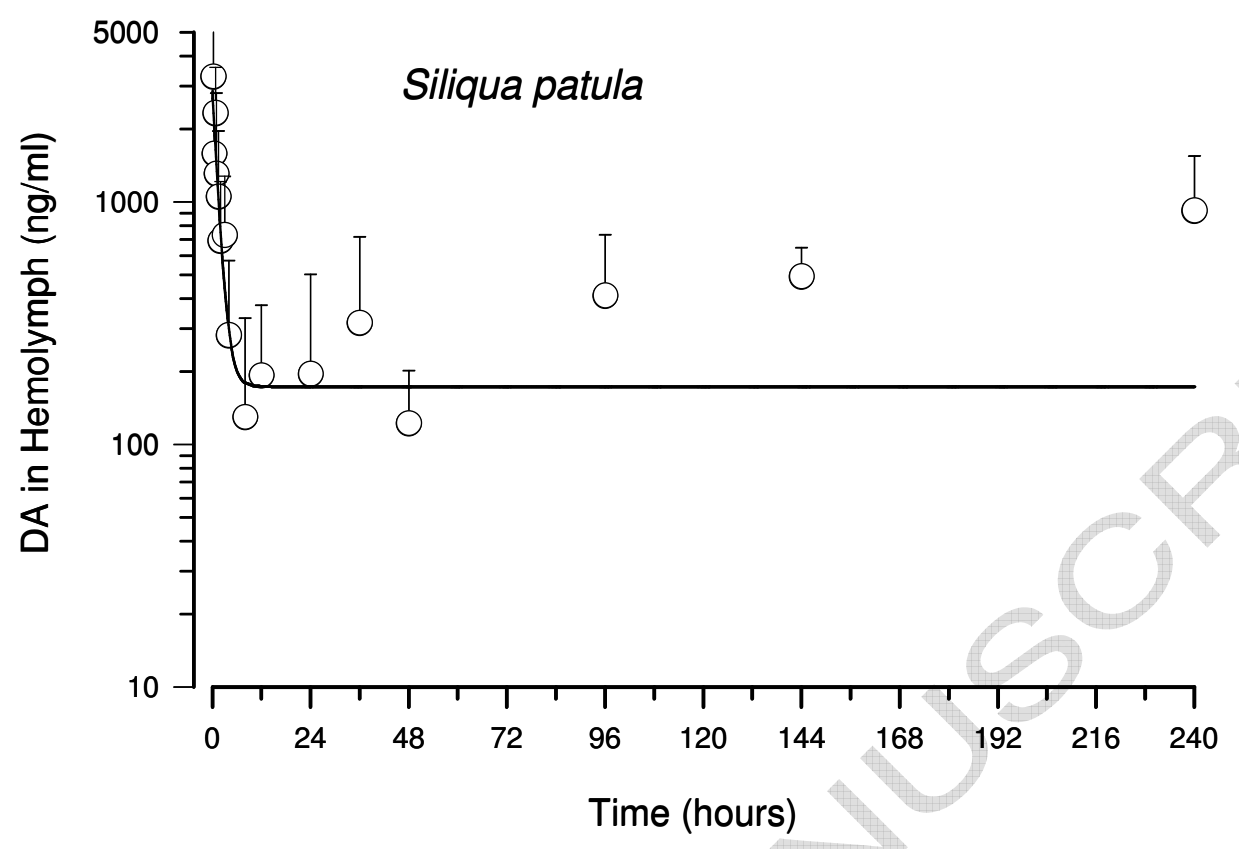

B)

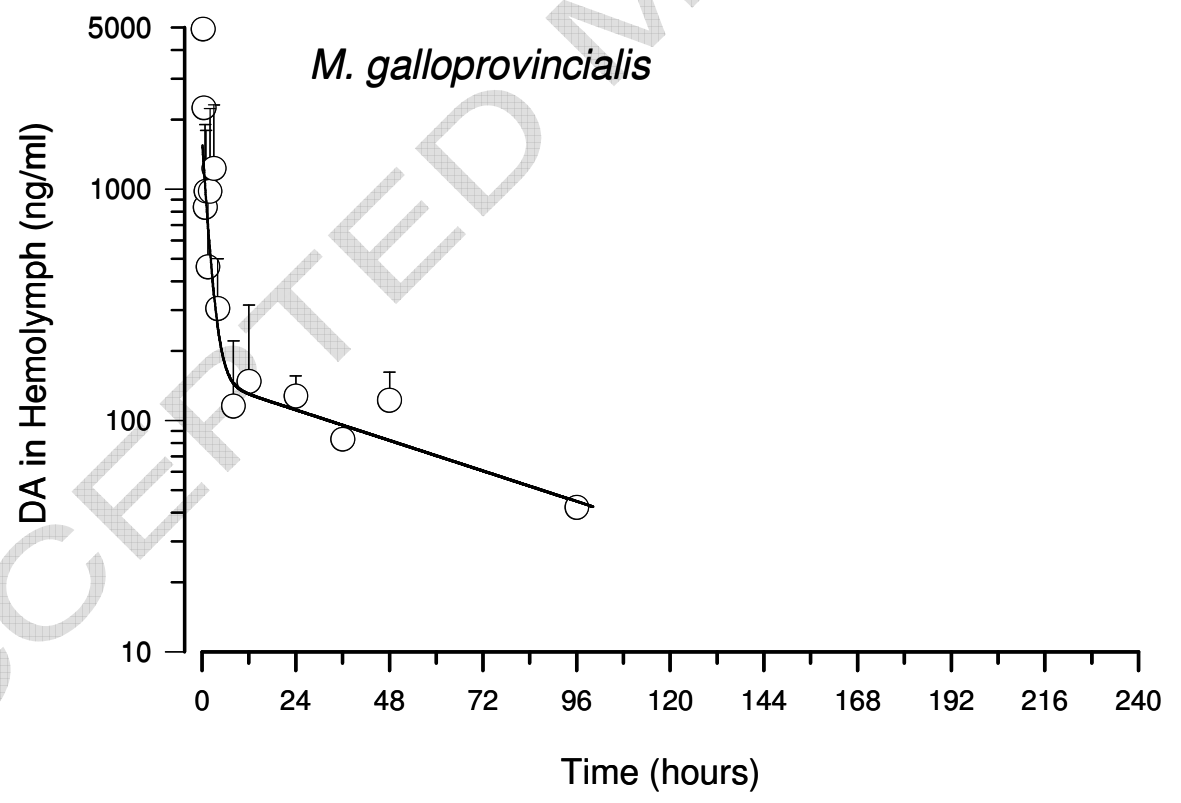

Figure 1 


\section{ACCEPTED MANUSCRIPT}

A)

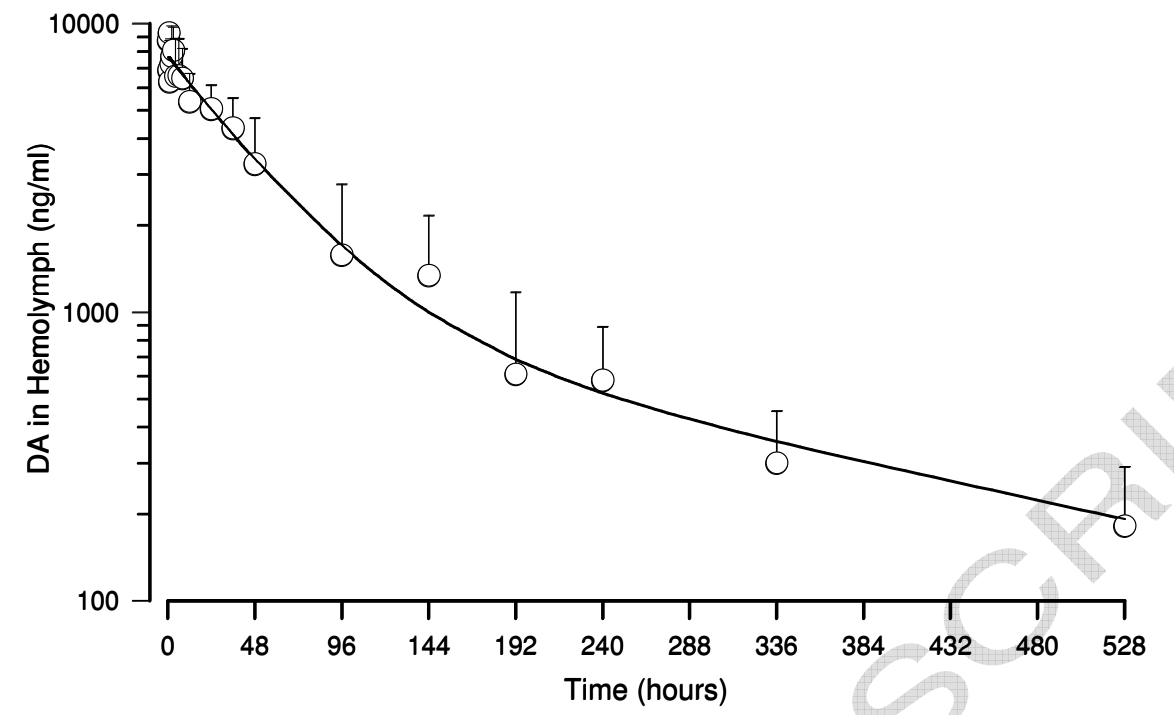

B)

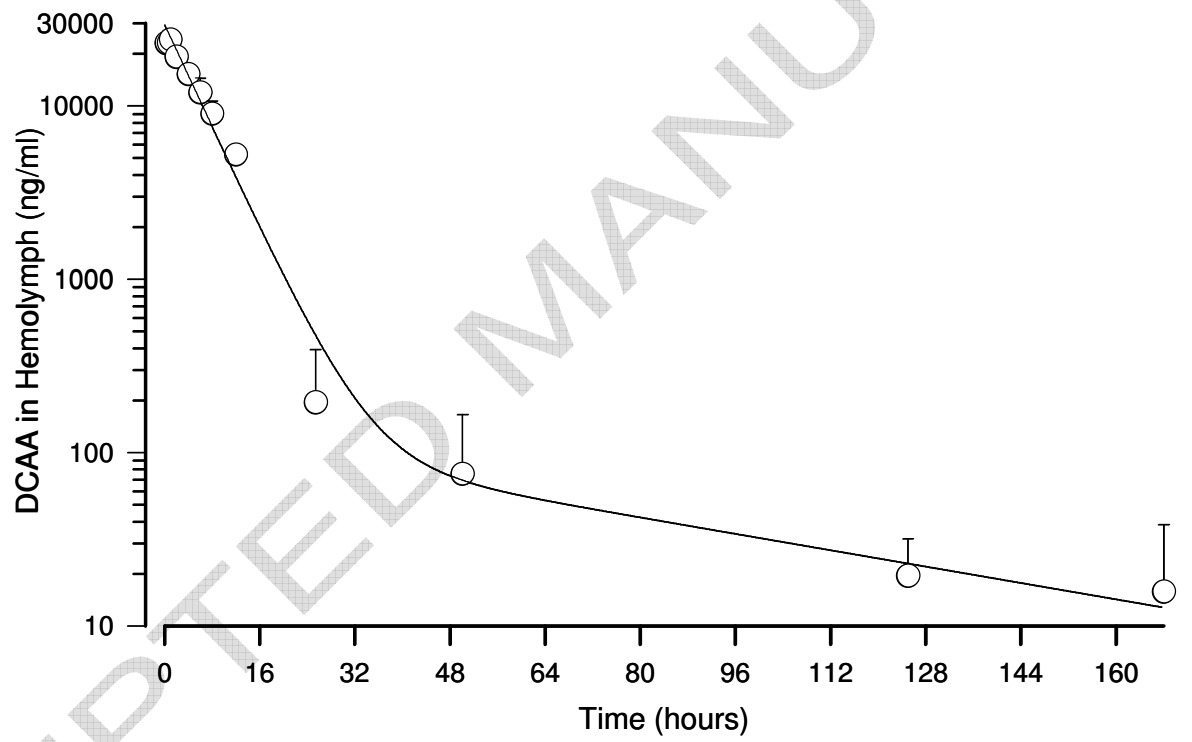

C)

Figure 2

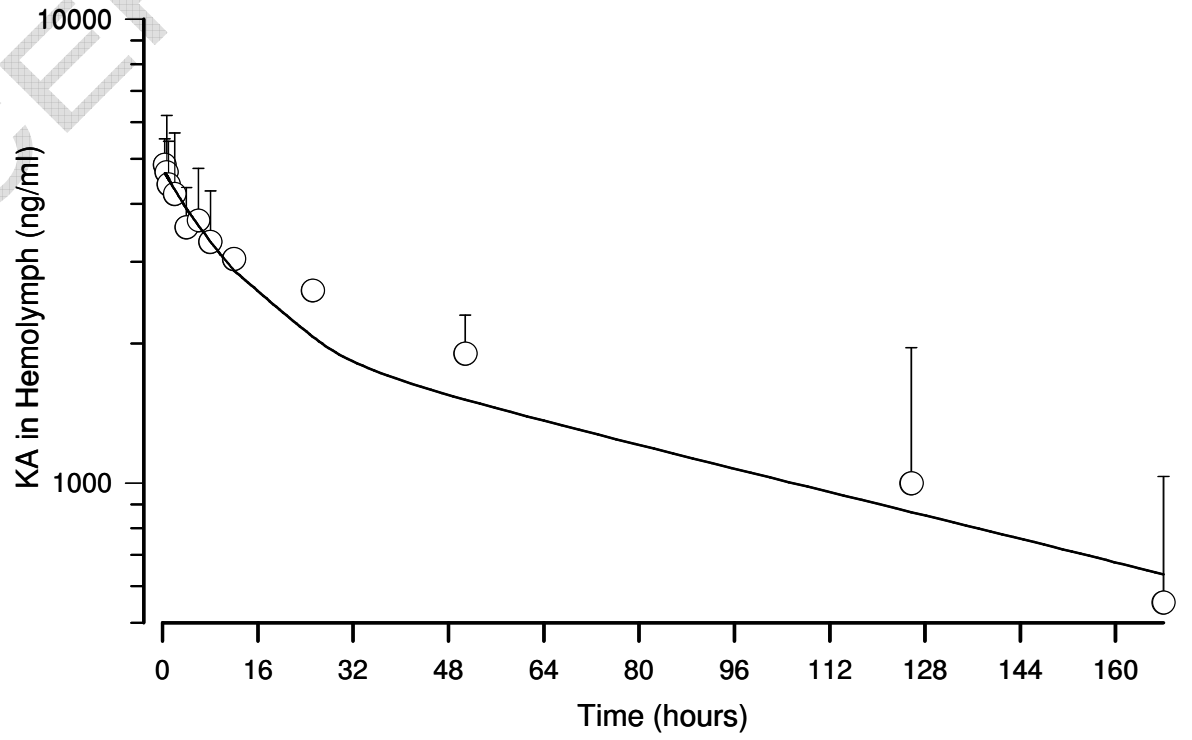

